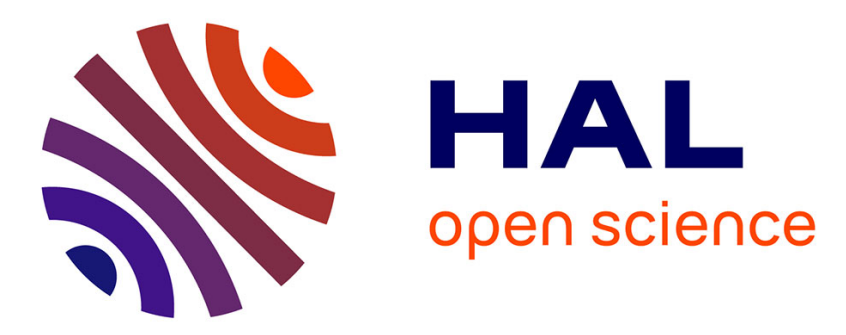

\title{
Optimizing metamorphosis in Paracentrotus lividus aquaculture using alternative macroalgae species to Corallina sp.
}

Marta Castilla-Gavilán, Vincent Turpin, Florence Buzin, Bruno Cognie, Priscilla Decottignies

\section{To cite this version:}

Marta Castilla-Gavilán, Vincent Turpin, Florence Buzin, Bruno Cognie, Priscilla Decottignies. Optimizing metamorphosis in Paracentrotus lividus aquaculture using alternative macroalgae species to Corallina sp.. Aquaculture International, 2018, 26 (6), pp.1511-1518. 10.1007/s10499-018-0305-8 . hal-01876022

\section{HAL Id: hal-01876022 \\ https://hal.science/hal-01876022}

Submitted on 26 Mar 2019

HAL is a multi-disciplinary open access archive for the deposit and dissemination of scientific research documents, whether they are published or not. The documents may come from teaching and research institutions in France or abroad, or from public or private research centers.
L'archive ouverte pluridisciplinaire HAL, est destinée au dépôt et à la diffusion de documents scientifiques de niveau recherche, publiés ou non, émanant des établissements d'enseignement et de recherche français ou étrangers, des laboratoires publics ou privés. 


\title{
Optimizing metamorphosis in Paracentrotus lividus aquaculture using alternative
} macroalgae species to Corallina sp.

Marta Castilla-Gavilán ${ }^{\mathrm{a} *}$, Vincent Turpin ${ }^{\mathrm{a}}$, Florence Buzin ${ }^{\mathrm{b}}$, Bruno Cognie ${ }^{\mathrm{a}}$, Priscilla Decottignies $^{\text {a }}$

${ }^{a}$ Université de Nantes, Institut Universitaire Mer et Littoral, EA 2160 Mer Molécules Santé, 2 rue de la Houssinière BP 92208, 44322 Nantes cedex 3 (France)

${ }^{\mathrm{b}}$ SARL Benth'Ostrea Prod, 17 rue du Pays de Monts, 85230 Bouin (France)

*Corresponding author at: Université de Nantes, Institut Universitaire Mer et Littoral, EA 2160 Mer Molécules Santé, 2 rue de la Houssinière BP 92208, 44322 Nantes cedex 3 (France). E-mail address: Mcasgavilan@gmail.com. Telephone: (+33) (0) 251125691

\begin{abstract}
Metamorphosis induction cues (by chemical mediation or direct contact) were tested in Paracentrotus lividus using three different macroalgae treatments: Corallina sp., Palmaria palmata and Laminaria digitata. Higher percentages of metamorphosis were reached in Paracentrotus lividus larvae by direct contact with a Palmaria palmata substrate.
\end{abstract}

Key words: Corallina sp.; Laminaria digitata; macroalgae; Palmaria palmata; recruitment; sea urchin

\section{Introduction}

World sea urchin fisheries have declined due to overexploitation (Conand and Sloan 1989; Kalvass and Hendrix 1997; Andrew et al. 2002). Today, aquaculture is the only realistic way to meet the increasing demand and the best way of protecting these species 
in the wild, which are important determinants of structure in benthic macrophyte communities (Harrold and Pearse 1987; Valentine and Heck 1991; Barillé-Boyer et al. 2004; Pearse 2006). In Europe, Paracentrotus lividus is the most consumed sea urchin species (Boudouresque 1987; Cook and Kelly 2009; Boudouresque and Verlaque 2013; Carboni et al. 2014) but its aquaculture remains anecdotal (FAO 2016). In fact, despite numerous studies conducted on the aquaculture of this species, many aspects still require investigation to enable the sustainable development of this activity in Europe.

Settlement and metamorphosis are critical steps in the Paracentrotus lividus life cycle in aquaculture as well as in the natural environment with a mortality rate reaching almost 99\% in the wild (Boudouresque and Verlaque 2013). In particular, it appears that the nature of the substrate is crucial for larvae recruitment (Cameron and Schroeter 1980; Pearce and Scheibling 1990). Previous studies have shown the inductive effect (by direct contact and/or chemical mediation) of a macroalgae substrate on the onset of metamorphosis in competent larvae of sea urchins: brown algae, non-coralline red algae and coralline red algae (Pearce and Scheibling 1991; Gosselin and Jangoux 1996; Hadfield and Paul 2001; Li et al. 2004).

Although coralline red algae provide the highest metamorphosis rate for sea urchins, these species are not suitable for farmers (small size, low biomass, difficult to harvest). In the context of the sustainable development of echinoculture in France, species abundant in the study area and used in sea urchin adult nutrition could be profitable for sea urchin farmers as settlement and metamorphosis inducers. Palmaria palmata and Laminaria digitata appear to be good candidates (Basuyaux and Blin 1998; Cook and Kelly 2007; Cook et al. 2007). Moreover these two species have shown a potential in the induction of Strongylocentrotus droebachiensis metamorphosis (Pearce and Scheibling 1991). 
The aim of this study was to investigate the inductive effect on the metamorphosis of $P$. lividus larvae of these three macroalgae: P. palmata, L. digitata and Corallina sp. as a reference species. Two different experiments were carried out in order to test this induction by direct contact and chemical mediation or by chemical mediation only.

\section{Materials and Methods}

Larvae of $P$. lividus were raised in the Benth'Ostrea Prod aquaculture farm (Bouin, Vendée, France). They were fed on a combined diet consisting of three microalgae species: Isochrysis aff. galbana (clone T-ISO), Rhodomonas sp. and Dunaliella tertiolecta. Throughout the cultivation period, larvae were stored at a density of 1 per $\mathrm{ml}$ for the first 17 days, then at 0.5 per $\mathrm{ml}$ until day 20 . Rearing was carried out in $2-\mathrm{m}^{3}$ conical PVC tanks in aerated seawater in continuous dark. A complete water exchange and thorough cleaning of the tanks was carried out every day. Twenty days after fertilisation, when most larvae were competent, they were transferred to the laboratory prior to experiments.

The macroalgae P. palmata (treatments $\mathrm{P} 1$ and $\mathrm{P} 2)$, Corallina sp. (C1 and $\mathrm{C} 2)$ and $L$. digitata (L1) were collected in May 2016 from the intertidal zone in Batz-sur-Mer, France (47'16'40.9' 'N 2 $29^{\prime} 39.8^{\prime}$ 'W), rinsed with filtered seawater and cleaned of epibionts and debris.

Batches of fifty competent larvae were transferred into sieves $(8-\mathrm{cm}$ high and $5-\mathrm{cm}$ diameter sieves with a bottom mesh of $200 \mu \mathrm{m}$ ). The sieves were then placed $1.5 \mathrm{~cm}$ above the bottom of the tanks $(25 \times 15 \times 10 \mathrm{~cm})$. Larvae were fed with $D$. tertiolecta $(8 \times$ $10^{4}$ cells/larvae day $^{-1}$ ) from the Nantes Culture Collection (NCC WDCM 856 from the Mer-Molécules-Santé Laboratory, Nantes, France). Flow-through seawater used throughout the process was filtered $(5 \mu \mathrm{m})$, UV treated and maintained at $20.6 \pm 1.1{ }^{\circ} \mathrm{C}$, 
$\mathrm{pH}$ of $8.1 \pm 0.1$ and salinity of $33.1 \pm 0.9$ (mean \pm S.D.) . As settlement cannot be directly observed, fixation was assessed by measuring the metamorphosis rate.

To test the chemical mediation, a first experiment (Fig. 1) was carried out by rearing 20 day-old larvae in macroalgae-conditioned seawater with an experimental design adapted from (Grosjean 2001). Macroalgae ("metamorphosis stimulating factors", MSF), cut into thalli of $2.5 \pm 0.1 \mathrm{~g}$ were placed in the tanks but outside the sieves. Four conditions were tested in triplicate: P. palmata (treatment P1), Corallina sp. (C1), L. digitata (L1) and a negative control (without algae). After three days, metamorphosis was only observed in $\mathrm{C} 1$ (first metamorphosed larvae appeared at day 2$)$ and at a very low rate $(<6.5 \%$; Fig. 2). Consequently, we decided to continue the experiment with a higher dose of MSF, which was doubled to $5 \pm 0.1 \mathrm{~g}$ in all the treatments.

To test the metamorphosis inductive effect of macroalgae in direct contact with larvae, a second experiment was carried out on 26 day-old larvae (Fig. 3). For this experiment, this work focused on P. palmata treatment (P2), given its common use among farmers and its easier harvesting, in contrast with a Corallina sp. treatment (C2; positive control) and an negative control (without algae). The MSF $(2.5 \pm 0.1 \mathrm{~g})$ was placed between two meshes in direct contact with larvae. This method enabled the larvae to remain in contact with the substrate and to be separated when larvae and juveniles were located and counted, thus reducing manipulations that are stressful for the larvae and time-consuming ((Pearce and Scheibling 1991).

In both experiments, the percentage of metamorphosed larvae and the survival rate were determined every $24 \mathrm{~h}$ in the sieves for all treatments and the control. The control without algae was used to estimate the percentage of larvae undergoing spontaneous metamorphosis. Experiments were conducted until the metamorphosis rate reached $90 \%$ in at least one of the batches (Figs. 2 and 4). 
Statistical analyses were performed using the SigmaPlot ${ }^{\circledR} 9.0$ software. Data were tested for normality prior to analysis and differences were then tested using a one-way ANOVA test. When the normality test failed, a Kruskal-Wallis one-way analysis of variance on ranks was used. Tukey's multiple comparisons test was carried out when significant differences $(P<0.05)$ were determined. Moreover, the survival rate in the two experiments was compared by a two-way analysis of variance.

\section{Results and Discussion}

In the first experiment, metamorphosis was observed in all treatments, but it was necessary to double the amount of MSF (Fig. 2). The metamorphosis rate was significantly higher in treatment $\mathrm{C} 1$ until day $5(P<0.001)$. Note that for treatments $\mathrm{C} 1$ and L1, metamorphosed larvae appeared earlier (day 2 and day 4, respectively) than in the control (day 5). In treatment P1, the first metamorphosed larvae appeared at the same time as in the control but at a higher percentage $(28.13 \pm 4.42 \%)$. On day 6 , no significant difference was observed between the three treatments and the control. However, although not statistically supported, percentages for the three treatments were always higher than the control, with a maximum obtained by treatment $\mathrm{C} 1(86.05 \pm 9.30 \%)$. These results indicate metamorphosis stimulation by macroalgae, which could be used to reduce the duration of this step of the rearing cycle. The results for Corallina sp. are comparable to those found by Grosjean et al (1998) using living Corallina elongata $(80.4 \%$ metamorphosis rate). For L. digitata, Gosselin and Jangoux (1996) did not observe any induction effect in larvae, perhaps due to the shorter duration of their experiment ( $24 \mathrm{~h})$. Concerning $P$. palmata, to our knowledge, this treatment has never been tested without direct contact.

The second experiment was carried out with half the amount of MSF compared to the first one $(2.5 \pm 0.1 \mathrm{~g})$. In this additional test, the metamorphosis rate reached $72.27 \pm$ 
$18.47 \%$ for larvae in treatment $\mathrm{C} 2$ and $57.19 \pm 6.34 \%$ for P2 in one day (Fig. 4). Metamorphosis rates for treatments C2 $(79.06 \pm 18.47 \%$ and $90.09 \pm 6.18 \%$ for days 2 and 3$)$ and P2 (84.48 $\pm 3.40 \%$ and $93.48 \pm 5.91$ for days 2 and 3$)$ were always significantly different $(P<0.001)$ from the control $(0 \%, 6.79 \pm 6.58 \%$ and $13.55 \pm 7.78 \%$ for days 1 , 2 and 3) but no differences were found between C2 and P2 (Fig. 4). This result indicates that the direct contact between larvae and the MSF causes an immediate effect on the metamorphosis rate, regardless of which algae are used and with a smaller amount of MSF, enabling the optimisation of this phase of sea urchin rearing. Direct contact seems crucial, but this result does not exclude the possibility that the induction of metamorphosis is due to chemical mediation and could be explained by a higher concentration of metabolites in the sieves (Hadfield and Paul 2001). Similarly, previous studies observed a metamorphosis induction effect by metabolites present in the Rhodophyta Delisea pulchra (Swanson et al. 2004, 2012), the algal host of the sea urchin Holopneustes purpurascens. Additional investigations could be carried out to determine the P. palmata metabolites involved in the induction of $P$. lividus metamorphosis observed in our study.

The results obtained in the present work confirm that coralline algae in contact with larvae lead to high metamorphosis rates, as already highlighted by previous studies (Pearce and Scheibling 1990, 1991; De la Uz et al. 2013). However, in their study, Pearce and Scheibling (1991) did not observe high values for larvae of Strongylocentrotus droebachiensis treated with $P$. palmata. It seems that the induction of sea urchin metamorphosis is not only macroalgae species-dependent but also sea urchin speciesdependent.

The higher metamorphosis rates obtained when algae were in contact with larvae could also be linked to the presence of microbial biofilms on the algae surface (Dworjanyn and Pirozzi 2008; Orvain et al. 2015). Indeed, natural biofilms are also widely used in $P$. 
lividus metamorphosis induction (Gosselin and Jangoux 1996; Liu et al. 2007; De la Uz et al. 2013; Brundu et al. 2016) as well as diatom-based biofilms (Rial et al. 2018; Zupo et al. 2018). Further research could also be done in this way. It would be interesting to investigate what type of biofilms naturally colonize the algae used in this study, isolate them and test their effectiveness as a metamorphosis inducer.

Survival results were significantly higher $(P<0.05)$ in the macroalgae-conditioned water system, compared to the second experiment. Survival rates in treatments P1 $(96.7 \pm$ $3.06 \%)$ and $\mathrm{P} 2(73.3 \pm 16.04 \%)$ were not significantly different from survival in treatments $\mathrm{C} 1(94.7 \pm 2.31 \%)$ and $\mathrm{C} 2(70 \pm 25.06 \%)$ (Fig. 5). According to Grosjean et al (1998), the survival of post-larvae settled on a correct substrate must be around $80 \%$ (immediately after settlement) for a profitable industrial production. In experiment 2, this threshold was not reached because of a high variability. However, the survival rate of at least one of the batches reached $90 \%$ with $P$. palmata and $94 \%$ with Corallina sp., showing a great potential of this method. Lower survival rates observed in some of the batches in experiment 2 could be explained by a poorer water circulation in the sieves caused by the clogging of the mesh by algae. This problem could be associated with the laboratory scale of the experiment and the need to separate larvae and substrate for the counting of larvae every day. At an industrial scale, clogging will be reduced by adding algae directly in contact with larvae in the same mesh because no counting is necessary until larvae are easy to observe (above 3-5 $\mathrm{mm}$ in diameter) despite the presence of the substrate.

\section{Conclusion}

The present study shows that the greatest percentages of metamorphosis can be reached in Paracentrotus lividus larvae when they are treated by direct contact with a "metamorphosis stimulating factor", which could be the red macroalgae Palmaria 
palmata, one of the most common sources of food for sea urchin adults (Vadas et al. 2000; Cook and Kelly 2007; Boudouresque and Verlaque 2013) and the most used in the area of this study by grazer invertebrate farmers such as sea urchin or abalone (GarcíaBueno et al. 2016). This method could be viable and profitable for optimising the hatchery production of Paracentrotus lividus. However, chemical mediation cannot be excluded from the effect of Palmaria palmata direct contact. Although direct contact appears essential, further research must be carried out to determine the Palmaria palmata metabolites involved in the induction of metamorphosis or the presence of a microbial biofilm associated with it surface.

\section{Acknowledgements}

This is a post-peer-review, pre-copyedit version of an article published in Aquaculture International journal. The final authenticated version is available online at: https://doi.org/10.1007/s10499-018-0305-8.

The authors wish to thank Clément Chauvin for his work during experiments and Richard Chagneau for providing the living resources. They are also grateful to Carol Robins for correcting the English of this communication. 


\section{Compliance with Ethical Standards}

This study was funded by the European project "Tools for Assessment and Planning of Aquaculture Sustainability" funded by the EU-H2020 research and innovation programme under Grant Agreement No 678396.

The authors declare that they have no conflict of interest.

This article does not contain any studies with human participants performed by any of the authors.

All applicable international, and/or institutional guidelines for the care and use of animals were followed. 


\section{References}

Andrew N, Agatsuma Y, Ballesteros E, et al (2002) Status and management of world sea urchin fisheries. Oceanogr Mar Biol: Ann Rev 40:343-425

Barillé-Boyer AL, Gruet Y, Barillé L, Harin N (2004) Temporal changes in community structure of tide pools following the "Erika" oil spill. Aquat Living Resour $17: 323-328$

Basuyaux O, Blin J-L (1998) Use of maize as a food source for sea urchins in a recirculating rearing system. Aquacult Int 6:233-247

Boudouresque CF (1987) Colloque international sur Paracentrotus lividus et les oursins comestibles. GIS POSIDONIE, Faculté des sciences de Luminy

Boudouresque CF, Verlaque M (2013) Paracentrotus lividus. In: Lawrence JM (ed) Sea urchins: Biology and ecology, 3rd edn. Elsevier, Amsterdam, pp 297-327

Brundu G, Monleón LV, Vallainc D, Carboni S (2016) Effects of larval diet and metamorphosis cue on survival and growth of sea urchin post-larvae (Paracentrotus lividus; Lamarck, 1816). Aquaculture 465:265-271

Cameron RA, Schroeter SC (1980) Sea urchin recruitment: effect of substrate selection on juvenile distribution. Mar Ecol- Prog Ser 2:243-247

Carboni S, Kelly MS, Hughes AD, et al (2014) Evaluation of flow through culture technique for commercial production of sea urchin (Paracentrotus lividus) larvae. Aquac Res 45:768-772

Conand C, Sloan N (1989) World fisheries for echinoderms. In: Caddy JF (ed) Marine invertebrate fisheries: their assessment and management. John Wiley \& Sons, pp 647-663

Cook E., Hughes AD, Orr H, et al (2007) Influence of dietary protein on essential fatty acids in the gonadal tissue of the sea urchins Psammechinus miliaris and Paracentrotus lividus (Echinodermata). Aquaculture 273:586-594

Cook EJ, Kelly MS (2009) Co-culture of the sea urchin Paracentrotus lividus and the edible mussel Mytilus edulis L. on the west coast of Scotland, United Kingdom. J Shellfish Res 28:553-559

Cook E., Kelly MS (2007) Effect of variation in the protein value of the red macroalga Palmaria palmata on the feeding, growth and gonad composition of the sea urchins Psammechinus miliaris and Paracentrotus lividus (Echinodermata). Aquaculture 270:207-217

De la Uz S, Carrasco JF, Rodríguez C, Anadon N (2013) Metamorphosis, growth and survival of early juveniles of Paracentrotus lividus (Echinodermata: Echinoidea): Effects of larval diet and settlement inducers. Cah Biol Mar 54:691-695 
Dworjanyn SA, Pirozzi I (2008) Induction of settlement in the sea urchin Tripneustes gratilla by macroalgae, biofilms and conspecifics: A role for bacteria? Aquaculture 274:268-274

FAO (2016) FAO yearbook. Fishery and Aquaculture Statistics. 2014. Rome, Italy

García-Bueno N, Turpin V, Cognie B, et al (2016) Can the European abalone Haliotis tuberculata survive on an invasive algae? A comparison of the nutritional value of the introduced Grateloupia turuturu and the native Palmaria palmata, for the commercial European abalone industry. J Appl Phycol 28:2427-2433

Gosselin P, Jangoux M (1996) Induction of metamorphosis in Paracentrotus lividus larvae (Echinodermata, Echinoidea). Oceanol Acta 19:293-296

Grosjean P (2001) Growth model of the reared sea urchin Paracentrotus lividus. Dissertation, Université Libre de Bruxelles

Grosjean P, Spirlet C, Gosselin P, et al (1998) Land-based, closed-cycle echiniculture of Paracentrotus lividus (Lamarck) (Echinoidea: Echinodermata): a long-term experiment at a pilot scale. J Shellfish Res 17:1523-1531

Hadfield MG, Paul VJ (2001) Natural chemical cues for settlement and metamorphosis of marine invertebrate larvae. In: McClintock JB, Baker BJ (eds) Marine Chemical Ecology. CRC Press LLC, pp 431-461

Harrold C, Pearse JS (1987) The ecological role of echinoderms in kelp forests. In: Jangoux M, Lawrence JM (eds) Echinoderm studies. CRC Press, pp 137-233

Kalvass PE, Hendrix JM (1997) The California red sea urchin, Strongylocentrotus franciscanus, fishery: catch, effort, and management trends. Mar Fish Rev 59:117

Li J-Y, Rahim S, Satuito CG, Kitamura H (2004) Characterization of the active substances in water conditioned by the coralline red alga Corallina pilulifera as inducers of metamorphosis in larvae of the sea urchin Anthocidaris crassispina. Sessile Organisms 21:41-46

Liu H, Kelly MS, Cook EJ, et al (2007) The effect of diet type on growth and fatty-acid composition of sea urchin larvae, I. Paracentrotus lividus (Lamarck, 1816) (Echinodermata). Aquaculture 264:247-262

Orvain F, Martinez A, Desoche E, Claquin P (2015) Chemical interaction between epilitic microphytobenthic biofilm and larval development of the sea urchin Paracentrotus lividus. M. Boutouil \& S. Leboulanger, ESITC Caen, pp 239-247

Pearce CM, Scheibling RE (1990) Induction of metamorphosis of larvae of the green sea urchin, Strongylocentrotus droebachiensis, by coralline red algae. Biol Bull 179:304-311

Pearce CM, Scheibling RE (1991) Effect of macroalgae, microbial films, and conspecifics on the induction of metamorphosis of the green sea urchin Strongylocentrotus droebachiensis (Müller). J Exp Mar Biol Ecol 147:147-162 
Pearse JS (2006) Ecological role of purple sea urchins. Science 314:940-941

Rial D, Rial P, Casal A, et al (2018) Induction of settlement, growth and survival of juveniles of Paracentrotus lividus. Aquaculture 483:16-20

Swanson RL, Byrne M, Prowse TAA, et al (2012) Dissolved histamine: a potential habitat marker promoting settlement and metamorphosis in sea urchin larvae. Mar Biol 159:915-925

Swanson RL, Williamson JE, De Nys R, et al (2004) Induction of settlement of larvae of the sea urchin Holopneustes purpurascens by histamine from a host alga. Biol Bull 206:161-172

Vadas RL, Beal B, Dowling T, Fegley JC (2000) Experimental field tests of natural algal diets on gonad index and quality in the green sea urchin, Strongylocentrotus droebachiensis: a case for rapid summer production in post-spawned animals. Aquaculture 182:115-135

Valentine JF, Heck KL (1991) The role of sea urchin grazing in regulating subtropical seagrass meadows: evidence from field manipulations in the northern Gulf of Mexico. J Exp Mar Biol Ecol 154:215-230

Zupo V, Glaviano F, Caramiello D, Mutalipassi M (2018) Effect of five benthic diatoms on the survival and development of Paracentrotus lividus post-larvae in the laboratory. Aquaculture 495:13-20 


\section{List of figures}

Fig. 1 Experimental design of experiment 1: larvae in contact with macroalgaeconditioned seawater. $\mathrm{MSF}=$ metamorphosis stimulating factor.

Fig. 2 Percentage of metamorphosed larvae in response to various macroalgaeconditioned seawaters. Data are expressed as mean \pm SD. Superscripts indicate significant differences $(\mathrm{P}<0.001 * * *) . \mathrm{P}=$ Palmaria palmata $; \mathrm{L}=$ Laminaria digitata $; \mathrm{C}=$ Corallina sp.

Fig. 3 Experimental design of experiment 2: larvae in direct contact with macroalgae. MSF $=$ metamorphosis stimulating factor.

Fig. 4 Percentage of metamorphosed larvae in response to various macroalgae in direct contact. Data are expressed as mean \pm SD. Superscripts indicate significant differences $\left(\mathrm{P}<0.001^{* * *}\right) . \mathrm{P}=$ Palmaria palmata $; \mathrm{C}=$ Corallina $\mathrm{sp}$.

Fig. 5 Percentage of larvae survival in the different treatments. Data are expressed as mean \pm SD. Superscripts indicate significant differences $\left(\mathrm{P}<0.05^{*}\right)$. Experiment $1=$ larvae in contact with macroalgae-conditioned seawater; Experiment $2=$ larvae in direct contact with macroalgae. 


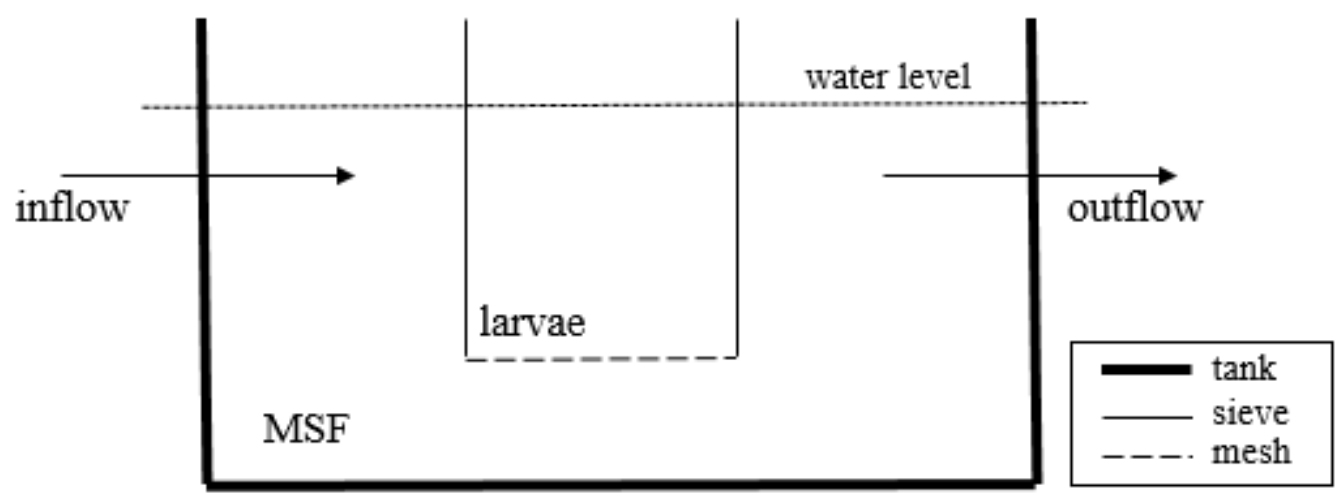

Fig. 1

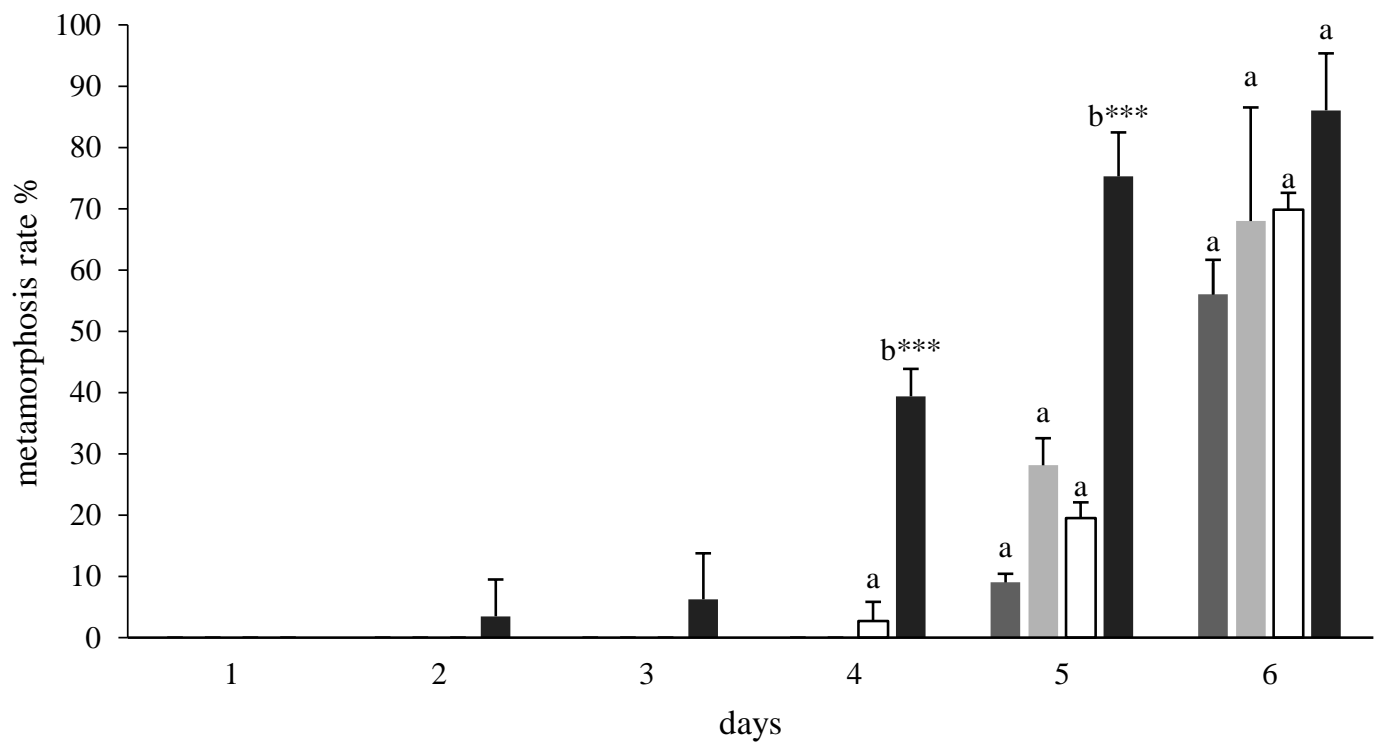

-Control $\square \mathrm{P} 1 \quad \mathrm{LL} 1 \backsim \mathrm{C} 1$

Fig. 2

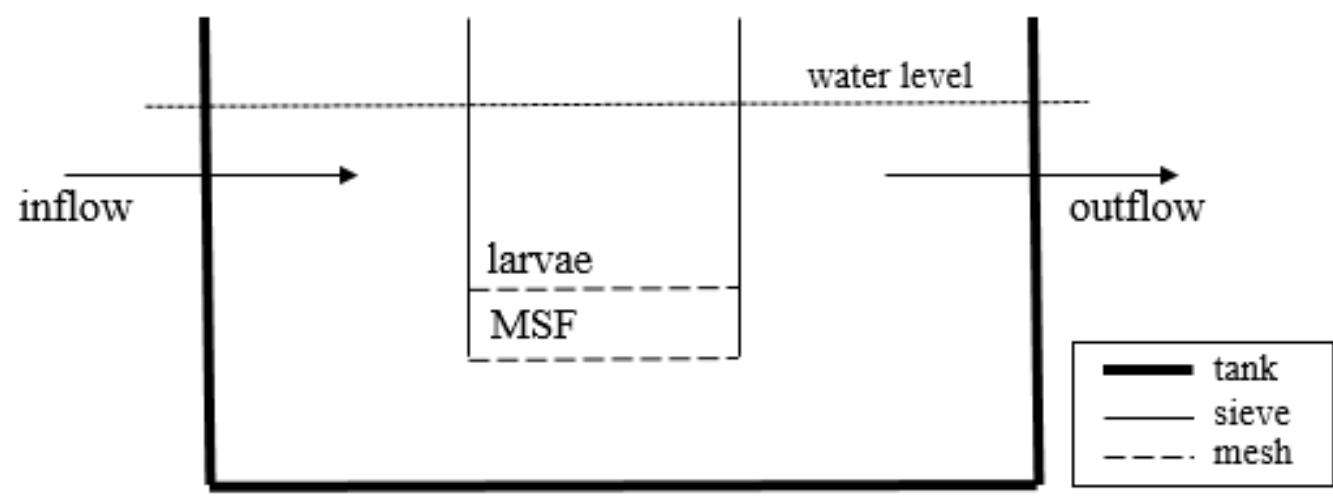

Fig. 3 


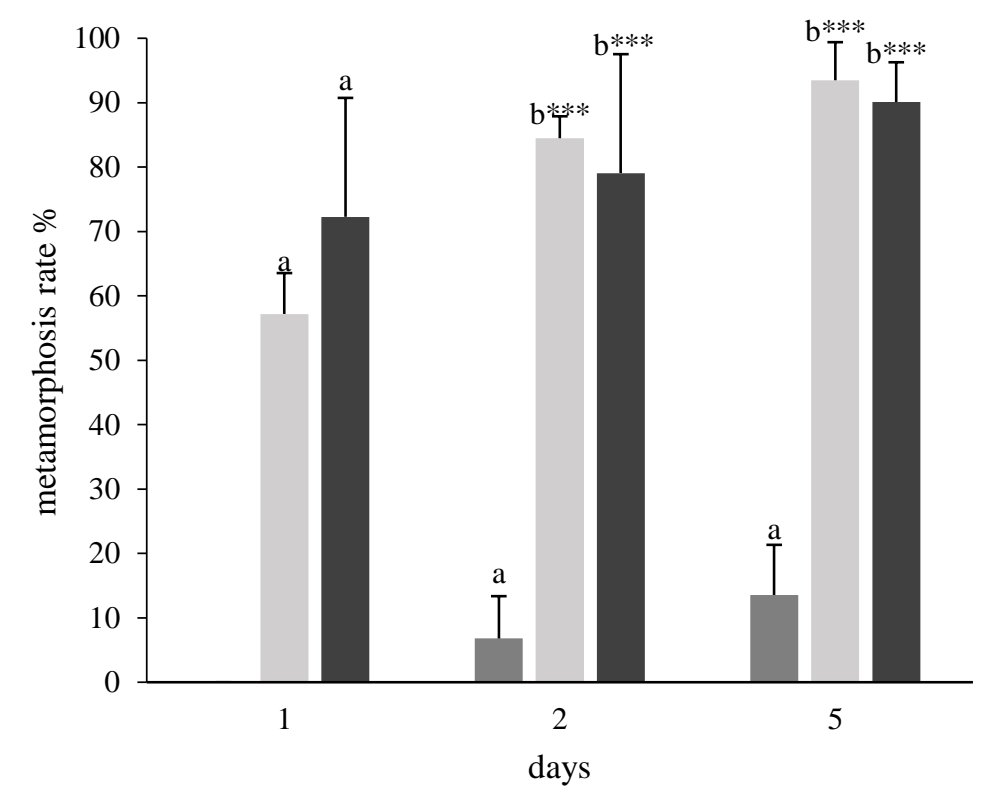

- Control $\backsim \mathrm{P} 2 \backsim \mathrm{C} 2$

Fig. 4

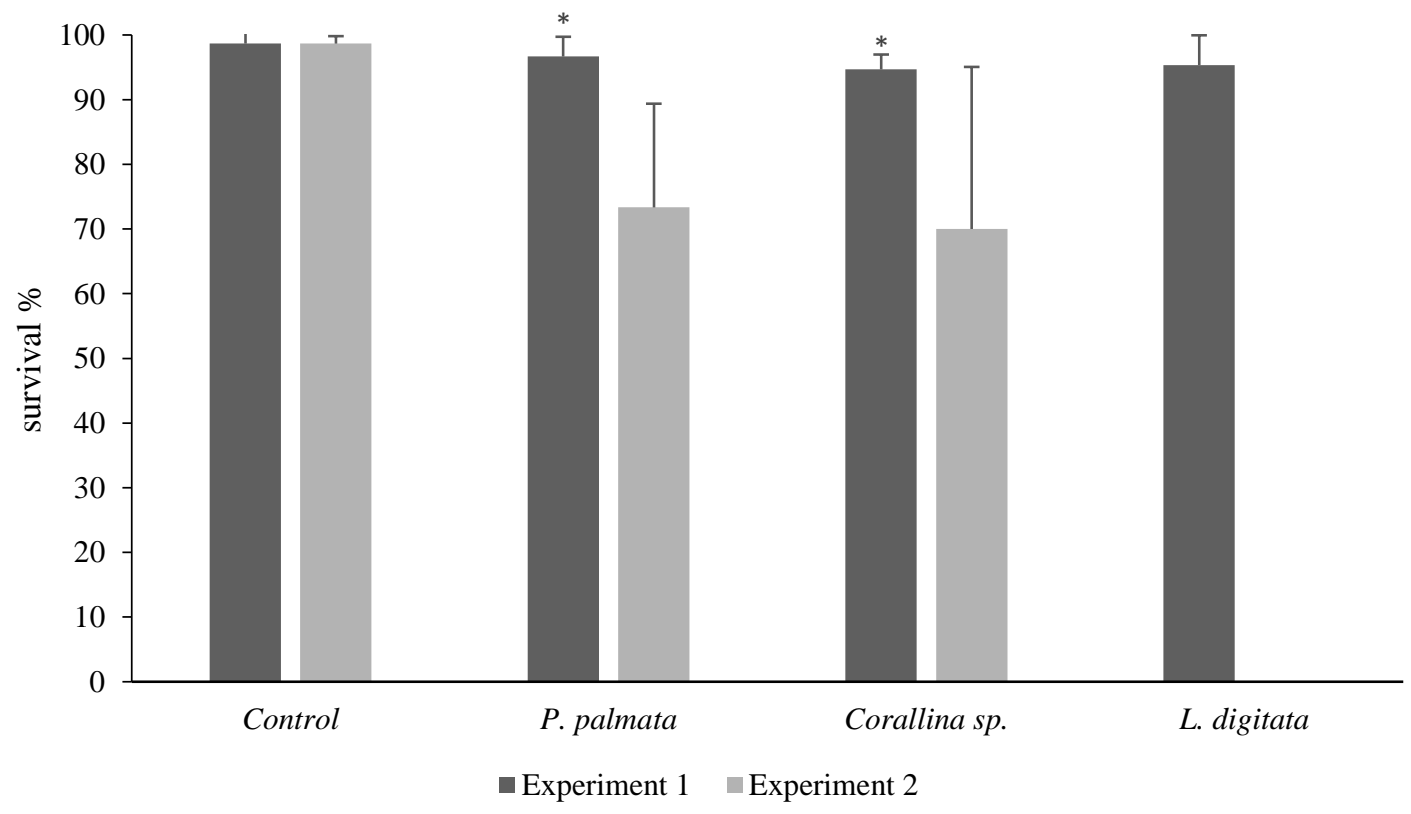

Fig. 5 